\title{
AMMONIA EMISSIONS REDUCTION POSSIBILITIES FROM DAIRY FARMS
}

\author{
Juris Priekulis ${ }^{1}$, Ligita Melece ${ }^{2}$ \\ ${ }^{1}$ Latvia University of Life Sciences and Technologies, Latvia; \\ ${ }^{2}$ Institute of Agricultural Resources and Economics, Latvia \\ juris.priekulis@1lu.lv, ligita.melece@arei.lv
}

\begin{abstract}
Ammonia emissions reduction possibilities from dairy farms, where liquid manure is produced, have been investigated. For comparison five technological versions have been selected that differ by the type of dairy cattle handling as well as manure management, particularly removal. Besides, also three ammonia emissions reduction options have been evaluated: usage of straw litter, usage of liquid manure chemical and bacteriological additives and pasturing of dry cows. For every production version the possible exploitation costs, euro per year, and the specific costs calculating per the amount of nitrogen left in manure, euro per $\mathrm{kg}$, have been determined. In the research it has been found that the most effective way of reduction of ammonia emissions is replacing of high boxes with deep boxes with straw litter. In this case, comparing with usage of high boxes, the manure removal costs as well as the specific costs that are referable to the amount of nitrogen left in manure are reduced by $30-35 \%$. Adding of chemical or bacteriological additives to liquid manure and pasturing of dairy cattle reduce the specific costs by 5-7\%. Nevertheless, in the calculations it has not been included that adding of these additives in manure collection canals that are installed in the barn reduces ammonia emissions not only in the barn, but also in the manure storage. Therefore, the obtained cost-effectiveness is even greater.
\end{abstract}

Keywords: cows, manure, ammonia, emissions.

\section{Introduction}

At present, in all large dairy farms liquid manure is produced [1]. Comparing to litter manure, liquid manure management of dairy cattle is easier to mechanise. Besides, the necessity for litter materials essentially reduces, in the result of what also the consumption of work in the farm reduces. Nevertheless, production of dairy cattle liquid manure causes larger emissions of ammonia, hydrogen sulphide and other unfavourable gases because of the dirty and wet area on the floor. Moreover, transferring from handling of dairy cattle tied to loose handling, increases emissions for about three times. Therefore, several additional measures described in special literature [2 -7] should be taken into account to reduce these emissions. However, not all of these measures can be implemented in practice. Due to this reason in our previous research $[8 ; 9]$ the most important measures for reduction of ammonia emissions were described using the expert method. But also this gives only approximate information. Therefore, the effectiveness of these measures should be evaluated by calculations.

The aim of the research: to determine the most effective technological solutions for liquid manure collection in dairy farms taking into account both cost-effectiveness and the reduction potential of ammonia emissions.

\section{Materials and methods}

It is possible to introduce modern milk production technologies and machinery, if in the herd there are not less than 100 cows [10]. At present in Latvia, in such conditions only $33 \%$ of all dairy cattle are kept, including herds from 100 to 299 cows $-16 \%$ of animals [11]. Nevertheless, building of new barns and reconstructing of the existing ones, as well as gradual concentration of dairy cattle and increasing of herds take place. Therefore, considering this fact, we chose a barn designed for 200 dairy cattle for our research. The possible version of a cross-section of such barn is given in Figure 1.

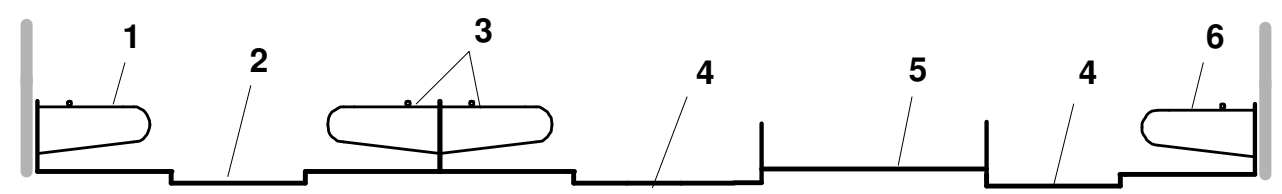

Fig. 1. Chosen barn cross-section for 200 cows; 1 - single box; 2 - manure duct between boxes;

3 - double box; 4 - manure duct at the feeding table; 5 - feeding table; 6 - dry cow box

There are recreation boxes for cows placed in four rows installed in the barn, but the animals are fed at the feeding table. Dairy cows are placed in one side of the feeding table, where there are three rows of recreation boxes. In turn, dry cows and cows with calves are on the other side of the feeding 
table, where there is one row of recreation boxes. The approximate length of the barn is $70 \mathrm{~m}$, the width $-32 \mathrm{~m}$.

In dairy farms different liquid manure removal technologies can be used [10; 12]. But the definite solution for these technologies is to a large extent determined by the kind of the planned boxes and litter (high or deep boxes, sand or straw litter). If, for instance, high boxes are used in the dairy cow barn, they are supplied with rubber mats or mattresses and a minimal amount of litter is used $(0.1-0.5$ $\mathrm{kg}$ per one bed depending on the kind of litter material). Stationary machinery is used for removal of manure from the barn. If, in turn, dairy cows are kept in deep boxes on sand litter, mobile machinery (tractor aggregate) is more suitable for removal of manure, as it does not wear so fast because of abrasive influence of sand.

The most characteristic technological versions of liquid manure collection, transportation and manure storage are summarised in Table 1.

Table 1

Characteristic of technological versions of liquid manure removal and manure storage

\begin{tabular}{|c|c|l|}
\hline $\begin{array}{c}\text { Types of cow } \\
\text { handling }\end{array}$ & $\begin{array}{c}\text { Version } \\
\text { No. }\end{array}$ & $\begin{array}{l}\text { Technological equipment and working operations for removal of } \\
\text { liquid manure from the barn and transportation to the manure } \\
\text { storage }\end{array}$ \\
\hline $\begin{array}{c}\text { High boxes } \\
\text { with rubber } \\
\text { mats }\end{array}$ & 1 & $\begin{array}{l}\text { Scraper conveyor with wire cable + flushing to intermediate storage } \\
\text { along cross - duct + intermediate storage with centrifugal pump and } \\
\text { flow switch + main pipeline + main storage. }\end{array}$ \\
\cline { 2 - 3 } & 2 & $\begin{array}{l}\text { Scraper conveyor with chain + cross - conveyor + intermediate } \\
\text { storage with mixer + piston type pump + main pipeline + main } \\
\text { storage. }\end{array}$ \\
\hline $\begin{array}{c}\text { Deep boxes } \\
\text { with straw } \\
\text { litter }\end{array}$ & 3 & $\begin{array}{l}\text { Scraper conveyor with wire cable + flushing to intermediate storage } \\
\text { along cross - duct + intermediate storage with centrifugal pump and } \\
\text { flow switch + main pipeline + main storage. Litter diffuser is } \\
\text { additionally needed. }\end{array}$ \\
\cline { 2 - 4 } & 4 & $\begin{array}{l}\text { Scraper conveyor with chain + cross - conveyor + intermediate } \\
\text { storage with mixer + piston type pump + main pipeline + main } \\
\text { storage. Litter diffuser is additionally needed. }\end{array}$ \\
\hline $\begin{array}{c}\text { Deep boxes } \\
\text { with sand litter }\end{array}$ & 5 & $\begin{array}{l}\text { Tractor with scoop + intermediate storage with centrifugal } \\
\text { pump + main pipeline + main storage. Litter diffuser is additionally } \\
\text { needed. }\end{array}$ \\
\hline
\end{tabular}

For the first two kinds of boxes correspondingly two sub - versions that are used in practice are chosen: the simplest and at the same time the cheapest as well as more complicated and correspondingly more expensive. Whereas for deep kinds of boxes that are filled with sand litter only one technological solution of liquid manure removal has been selected - using the tractor aggregate. This aggregate transports manure to the intermediate storage, where sedimentation of sand takes place. Therefore, transportation of liquid manure to the main storage can be done by the centrifugal pump, bur sediments can be emptied by the scoop mounted to the tractor.

The technological versions were compared according to the specific exploitation costs, EUR/cow per year. For calculation of these criteria correspondingly developed software was used. The necessary input data were obtained from the results of our chronometer data, valid normative documents, price lists and technical instructions, but in some cases the information available from the companies "DeLaval" and "GEA" was used.

Considering the results of the expert inquiry [8], the following efficiency of introduction of measures for reduction of ammonia emissions was evaluated:

- Usage of moisture absorbent materials in animal beds, for example, straw litter.

- Pasturing of dry cows.

- Usage of liquid manure chemical or biological additives.

Knowing the losses of nitrogen, which is in manure, during manure removal [13] as well as assuming that these nitrogen losses are proportional to the amount of ammonia emissions, the specific 
exploitation costs can be calculated that arise per one kilogram of nitrogen left in manure implementing different measures to reduce ammonia emissions.

In case, if straw is used in animal beds

$$
I_{N . s}=\frac{I E_{\bar{i} p}}{x_{b}+\frac{\left(x_{s}-x_{b}\right) \cdot \lambda_{s}}{100}},
$$

where $I_{N . s}-$ specific costs calculating per one $\mathrm{kg}$ of amount of nitrogen left in manure,

EUR. $\mathrm{kg}^{-1}$;

$I E_{\bar{i} p}$ - specific exploitation costs, EUR $\cdot$ cow $^{-1} \cdot$ year $^{-1}$;

$x_{s}$ and $x_{b}$ - amount of nitrogen in cow manure (urine and solid excrements) and manure collected in the shed, $\mathrm{kg} \cdot \mathrm{cow}^{-1}$ year $^{-1}$. According to the data in literature $[13 ; 14], x_{s}$ is in average $152 \mathrm{~kg} \cdot \mathrm{cow}^{-1} \cdot \mathrm{year}^{-1}$, but $x_{b}$ is $129 \mathrm{~kg} \cdot \mathrm{cow}^{-1} \cdot \mathrm{year}^{-1}$;

$\lambda_{s}-$ reduction of ammonia emissions using straw litter, \%; ccording to literature $[2 ; 4]$ $\lambda_{s} \sim 70 \%$.

In turn, if dry cows are pastured, then

$$
I_{N . g}=\frac{I E_{\bar{i} p}}{x_{b}+\frac{\left(x_{s}-x_{b}\right)}{100} \cdot \frac{365-t_{g}}{365} \cdot \frac{365-t_{c}}{365}},
$$

where $I_{N . g}$ - specific costs calculating per one $\mathrm{kg}$ of amount of nitrogen left in manure, EUR $\mathrm{kg}^{-1}$;

$t_{g}$ - length of the pasturing period, days.year ${ }^{-1}$; according to the research at the Latvia University of Life Sciences and Technologies [1] $t_{g}=196$ days;

$t_{c}$ - length of cow dry period, days. year ${ }^{-1}$;

365 - number of days in the year.

If liquid manure chemical or biological additives are used as means to reduce emissions, then

$$
I_{N . p}=\frac{I E_{\bar{i} p}+I E_{p}}{x_{b}+\frac{\left(x_{s}-x_{b}\right) \cdot \lambda_{p}}{100}},
$$

where $I_{N \cdot p}$ - specific costs calculating per one $\mathrm{kg}$ of amount of nitrogen left in manure, EUR $\cdot \mathrm{kg}^{-1}$;

$I E_{p}$ - additional exploitation costs related to using of chemical or biological additives, EUR $\cdot \operatorname{cow}^{-1} \cdot$ year $^{-1}$; according to our calculations using the additive GÜLLEMAX, $I E_{p}=3,3 \mathrm{EUR} \cdot \mathrm{cow}^{-1} \cdot$ year $^{-1}$;

$\lambda_{p}$ - reduction of ammonia emissions using liquid manure additives, \%; based on the data of the research in Austria and Germany [15], it is assumed that $\lambda_{p}=50 \%$.

\section{Results and discussion}

The dairy cattle manure removal exploitation costs obtained by calculations are summarised in Figure 2.

The total exploitation costs include expenses for machinery as well as salaries for the workers. That is why it is possible to evaluate the cost-efficiency of every technology considering these expenses.

According to Figure 2, it can be concluded that version 3, when dairy cows are kept in deep boxes with straw - manure litter and transportation of manure is done using the recirculation principle in the cross- duct, requires the least expenses. If, in turn, manure is transported along the cross - duct by the conveyor, the exploitation costs increase almost by $24 \%$. The expenses are even greater (by $58 \%$ and $80 \%$ ) for versions 2 and 5 . For version 2 it is related to the necessity to purchase mats, but for version 5 - usage of the tractor and salary for the tractor driver. 


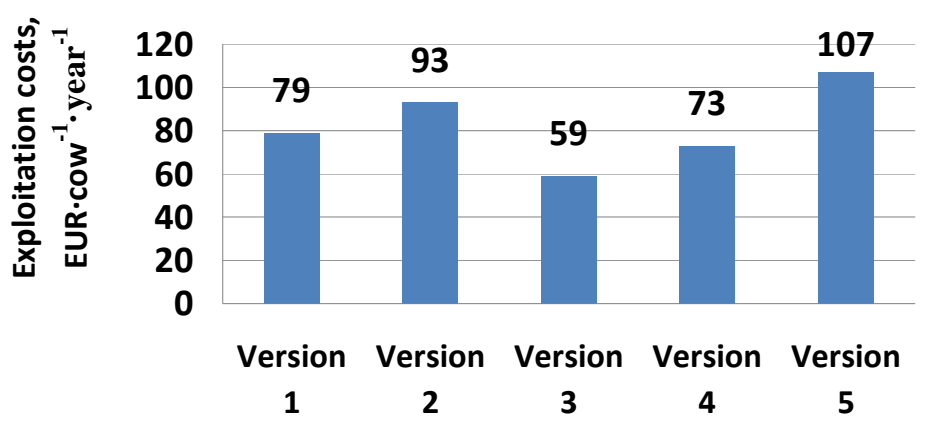

Fig. 2. Total exploitation costs, EUR $\cdot \operatorname{cow}^{-1} \cdot$ year $^{-1}$, for removing of dairy cow manure

The specific exploitation costs calculating per one $\mathrm{kg}$ of nitrogen left in dairy cow manure using different ammonia emission reduction measures are shown in Figure 3.

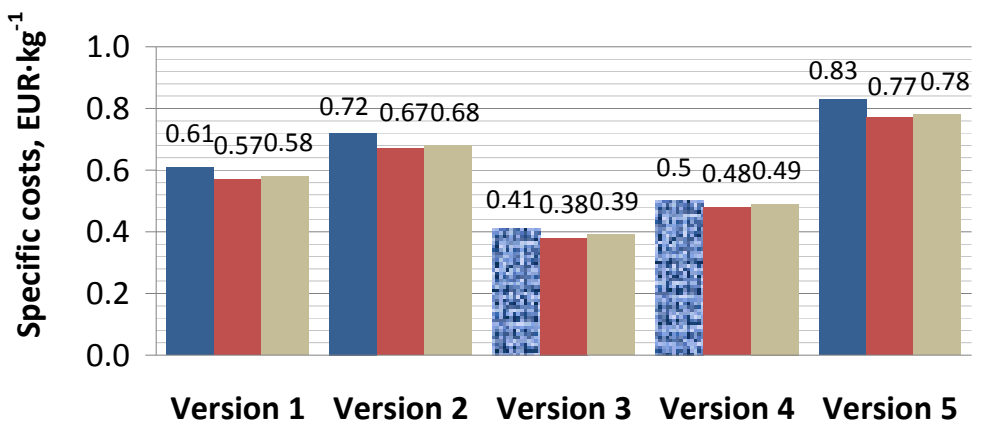

Considering that in versions 3 and 4 straw litter is used

Pasturing dry cows

Using special additive GÜLLEMAX

Fig. 3. Specific costs calculating per amount of nitrogen left in manure, EUR $\mathbf{k g}^{-1}$

Note: the basic version is given in dark blue, when emission reduction measures are not used

The summarised calculation results show that the least expenses, calculating per one kilogram of nitrogen left in liquid dairy cow manure, are in versions 3 and 4, where the deep boxes with straw litter are used. In this case straw is regularly spread in the cow beds; it absorbs moisture and emissions of unfavourable gases, including ammonia emissions. Therefore, from the point of view of reduction of ammonia emissions, it is not efficient to use high boxes as well as deep boxes with sand litter.

It is also possible to use special liquid manure additives, for instance, the additive GÜLLEMAX offered by the company "Plant Protection Service". The calculations show that usage of these additives reduces the specific costs approximately by $5 \%$. Nevertheless, it should be noted that this additive will retain its influence also during storage of dairy cattle manure, what will increase the costeffectiveness of its usage even more.

Also pasturing of dairy cattle reduces ammonia emissions. But it can be done mainly with dry cows, which do not need to be milked. Otherwise it causes organisational difficulties and also the milk yields can be reduced. Pasturing of dry cows reduces the specific costs by $7 \%$. Still, the obtained results of calculations are approximate, as in these the pasturing exploitation costs as well as the costs of pasture grass compared to usage of preserved forage are not considered. Besides, pasturing is possible only in the period of plant vegetation.

\section{Conclusions}

1. Evaluating according to reduction of ammonia emissions, deep boxes with straw - manure litter are more rational. Compared to using of high boxes, in this case the exploitation costs for dairy cow manure removal as well as the specific costs in relation to the amount of nitrogen left in manure are reduced by $30-35 \%$.

2. Usage of chemical or bacteriological additives as well as pasturing of dairy cattle, particularly dry cows, reduces the specific costs by 5-7\%. Nevertheless, in the calculations it has not been included that adding of these additives in manure collection canals that are installed in the barn 
reduces ammonia emissions not only in the barn, but also in the manure storage. Therefore, the obtained cost-effectiveness is even greater.

\section{Acknowledgements}

This study was supported by the Ministry of Agriculture of the Republic of Latvia as a part of the research project "Selection and assessment of effectiveness of ammonia emissions mitigation and reduction measures in agriculture" (No 10.9.1-11/17/886).

\section{References}

[1] Laurs A., Priekulis J., Markovičs Z. and Āboliņ̌s A. Research in farm animal breeding technological parameters. $/ 15^{\text {th }}$ International Scientific Conference "Engineering for rural development". Proceedings, Volume 15. Jelgava, May 25-27, 2016. pp.1054.-1058.

[2] Directive (EU) 2016/2284 of the European Parliament and of the Council of 14 December 2016 on the reduction of national emissions of certain atmospheric pollutants, amending Directive 2003/35/EC and repealing Directive 2001/81/EC. Official Journal of the European Union, L 344, pp. 1-31.

[3] UNECE 2014. Guidance document on preventing and abating ammonia emissions from agricultural sources. ECE/EB.AIR/120. [online][19.03.2018] Available at: https://www.unece.org/environmental-policy/conventions/envlrtapwelcome/guidance-documentsand-other-methodological-materials/gothenburg-protocol.html

[4] Bittman S. u.c. Amonjaka emisijas samazināšanas iespējas (Ammonia emission reduction options) /ANO Eiropas Ekonomiskās komisijas Ķīmiski aktīvā slāpekḷa darba grupas metodiskie norādījumi. Valsts valodas centrs, 2015. 108 lpp. (In Latvian)

[5] Barwicki J., Savinyh P., Kubon M., Marczuk A. Animal waste management in some European countries located in the Baltic sea region in terms of reducing nitrogen losses from slurry and protecting atmosphere and water. Monograph under the scientific editorship of prof.W.Romaniuk. Falenty - Warsaw, 2017. pp.1 7-24.

[6] UNECE 2015. Framework Code for Good Agricultural Practice for Reducing Ammonia Emissions. ECE/EB.AIR/129. [online][19.03.2018] Available at: https://www.unece.org/environmental-policy/conventions/envlrtapwelcome/guidance-documentsand-other-methodological-materials/gothenburg-protocol.html

[7] Eurich B., Döhler H., Dämmgen U. Ammoniak-Emissionen der deutschen Landwirtschaft technische Minderungspotenziale. Landtechnik, 3/2004.

[8] Laurs A., Priekulis J., Melece L. Reduction of ammonia emissions collecting and storing farm manure. /Problems of intensification of animal production including environment protection and alternative energy production as well as biogas. Monograph under the scientific editorship of prof.W.Romaniuk. Falenty - Warsaw, 2017. pp. 93.-96.

[9] Markovičs Z. Ekspertu novērtējumu metodes. RTU, Rīga, 2009. 111 pp. (In Latvian)

[10] Priekulis J. Efficient technology and mechanisation in dairy farming. Jelgava: LLU, 2000. 148 pp. (In Latvian)

[11] Latvijas lauksaimniecība 2016 (Latvian agriculture 2016). LR Zemkopības ministrija. 2017. 155 lpp. [online][19.03.2018] Available at: www.zm.gov.lv (In Latvian)

[12] Gridnev P., Gridneva T., Romaniuk W. The influence of livestock premises manure removal al mechanical systems on nitrogen's losses. Monograph under the scientific editorship of prof.W.Romaniuk. Falenty - Warsaw, 2017. p.72.-76.

[13] Kārkliņš A,.Līpenīte I. Daži kūtsmēslu normatīvu izstrādes metodiskie aspekti (Some methodological aspects of the development of manure standards). LLU Raksti (21) 2008. 11.21.lpp. (In Latvian)

[14] Ministru Kabineta noteikumi Nr. 834. Noteikumi par ūdens un augsnes aizsardzību no lauksaimnieciskās darbības izraisītā piesārņojuma ar nitrātiem. Spēkā no 23.12.2014. (In Latvian) (Regulations No. 834 of the Cabinet of Ministers of the Republic of Latvia. Regulations on protection of water and soil from pollution with nitrates caused by agricultural activities. In force from 23.12.2014. (In Latvian)

[15]Enhance forage crops. [online][19.03.2018] Available at: http://www.amalgerol.com/en/animalbarn/guellemax/ 